\title{
SOIL GENOTOXICITY BIOMONITORING IN RECULTIVATED FACTORY AREA USING THE CYTOGENETIC AND MOLECULAR ASSAYS IN TWO PLANT TEST-SYSTEMS
}

\author{
Asta STAPULIONYTÉ, Institute of Biosciences, Life Sciences Center Vilnius University, Sauletekio Ave. 7, LT-10257 Vilnius, \\ Lithuania; asta.stapulionyte@gf.vu.lt (corresponding author) \\ Skaistė BONDZINSKAITE், Institute of Biosciences, Life Sciences Center Vilnius University, Saulètekio Ave. 7, LT-10257 Vilnius, \\ Lithuania; skaiste.bond@gmail.com \\ Monika STRAVINSKAITE், Institute of Biosciences, Life Sciences Center Vilnius University, Saulètekio Ave. 7, LT-10257 Vilnius, \\ Lithuania; monika.stravinskaite@gf.stud.vu.lt \\ Raimondas ŠIUKŠTA, Institute of Biosciences, Life Sciences Center Vilnius University, Saulètekio Ave. 7, LT-10257 Vilnius, \\ Lithuania; raimondas.siuksta@gf.vu.lt \\ Ričardas TARAŠKEVIČIUS, Institute of Geology and Geography, Nature Research Centre, Akademijos Str. 2, LT-08412, Vilnius, \\ Lithuania; ricardas.taraskevicius@gmail.com \\ Tatjana Č́ \\ Lithuania; egle.cesniene@gf.vu.lt
}

Soil pollution with industrial leftovers is of real danger to living organisms since harmful effects can arise after exposure to the contaminants in the soil. In our study, we applied a plant bioassay battery to monitor soil genotoxicity after short-term exposure to the soil. The soil was collected in 3 rounds: at the central part of the brownfield before (S-I) and after (S-III) topsoil removal, and at the brownfield periphery (S-II). The permissible value of the total contamination index is $<16$ and the corresponding values were 780 in S-I, 69 in S-II and 133 in S-III soil showing that whole brownfield territory is extremely polluted with heavy metals. Cytogenetic markers were recorded in Allium and Tradescantia test-systems and two types of molecular markers, RAPD and ISSR, were analysed in Allium. Our results revealed that the most polluted soil sample has induced an alarming increase of apoptotic cells in onion roots. Chromosome aberration and micronuclei frequency in Allium decreased inconsistently along with the pollution reduction in the soil. Increased frequencies of all cytogenetic markers were revealed in Tradescantia cuttings after exposure to the S-I soil extracts. Cluster analysis of Allium RAPD and ISSR markers showed that the most polluted soil samples induced genetic changes in onions different from those induced by the least polluted soil. Both plant test-systems in this study confirm that soil from the brownfield is harmful to plants and is potentially hazardous to humans.

Keywords: Allium, cytogenetic markers, ISSR, PHEs, RAPD, soil genotoxicity, Tradescantia

\section{INTRODUCTION}

Electronic equipment production is among other industrial sectors releasing large quantities of toxic materials. Inorganic chemicals such as lead, chromium, nickel, arsenic account for $>99 \%$ of the annual carcinogenic releases . Chromium and arsenic compounds are well-known mutagens that can act as clastogens (White, Claxton, 2004). Environmental pollution at the abandoned areas of industrial establishments, landfill sites is of real danger when left without proper conservation and management (Bleicher, Gross, 2010; Čésnienè et al., 2010) or recultivated carelessly. Ecological revitalization of such contaminated sites into residential zones is a constant process issued by the need to satisfy an increasing population demand for the housing (Schädler et al., 2011; Bondzinskaite et al., 2017) also promoted by environmental awareness raised with increasing knowledge about consequences of improper waste disposal (Bleicher, Gross, 2010; Silvia et al., 2011). Special care must be taken into assuring cleaning of ecological risk areas due to the potential threat of various toxicant leftovers (Schädler et al., 2011) in the soil, and every organism directly or indirectly is dependent on its quality. There are cases when demolishing wreckage together with soil admixture are reused for rural road restoration or sewage sludge is used in arable fields as fertilizer (Silvia et al., 2011; Aguiar et al., 2016).

Biological monitoring through biomarkers of exposed living organisms provides a tool for the identification of pollutants (Conte et al., 1998) that may cause damage to human health (Singh, 2017). The most popular bioassays in soil genotoxicity assessment are Salmonella mutagenicity test and four plant assay systems: the stamen hair mutation assay in Tradescantia (Trad-SHM), the Tradescantia micronucleus test (Trad-MN), the anaphase aberration test in Allium cepa root tip, and the waxy locus mutation assay in Zea mays (White, Claxton, 2004). Plants, as biological indicators, can

Copyright (C) 2017 The Authors. Published by Aleksandras Stulginskis University. This is an open-access article distributed under the terms of the Creative Commons Attribution License (CC-BY 4.0), which permits unrestricted use, distribution, and reproduction in any medium, provided the original author and source are credited. 
measure both the actual and the potential effects of organic and inorganic pollutants (Conte et al., 1998) and enable assessing the effects of simple or complex compounds present in the environment. The results obtained with the plant model systems can be extrapolated to other living organisms, including humans (Bernardes et al., 2015).

Molecular markers can be applied not only for polymorphism studies but also to detect deleterious heavy metal effects on DNA integrity by comparing variation in DNA banding profile between treated and untreated organisms. Effects of heavy metals can be easily detected in plants by application of RAPD (Pal, Kundu, 2015) and ISSR markers (Al-Qurainy, 2010). Both marker systems are highly polymorphic and are considered efficient in the evaluation of the genotoxic activity of heavy metals (Bernardes et al., 2015), nevertheless there is a deficiency of soil genotoxicity studies involving Allium RAPD or ISSR markers as predominantly only various toxic liquids (Chandra et al., 2005) and heavy metals are tested mostly by classical cytogenetic methods (Kataeva et al., 2012). Molecular marker application for genotoxicity assessment in Allium so far includes only hospital wastewater analysis by RAPD application (ZiembińskaBuczyńska et al., 2016) and fungicide effect testing by ISSR application (Bernardes et al., 2015).

Our aim was to monitor soil genotoxicity for the three year period at the brownfield that is recultivated into a residential zone and where the main concern is the management of the contaminated soil. Special attention must be paid on what possible genotoxic impact on the environment the contaminated soil may load if not managed appropriately or even worse - reused for rural environment improvement like road restoration, where its dangerous compounds can spread by leaching. The most popular plant test-systems, A. cepa and Tradescantia \#4430, were chosen for soil monitoring as both are good indicators of cytogenetic and mutagenic effects and are widely used for detection of harmful effects induced by various types of toxicants (Cotelle et al., 1999; Majer et al., 2002; White, Claxton, 2004). We applied a bioassay battery of classical bioassays, such as chromosome aberration assay and MN test, along with the molecular DNA markers to investigate soil quality and determine its possible genotoxic effects on plants that could be extrapolated to humans.

\section{MATERIALS AND METHODS}

\section{Soil sampling}

16 composite soil samples (Table 1) were collected at the abandoned electrical equipment factory 'Skaiteks' area (N 54 40' 46.87", E 25 18' 7.92") in Vilnius city. Sampling was done in 3 rounds in the subsequent years: 1) samples at 9 points collected in 2013 at the central part of the brownfield before the recultivation start (site S-I), 2) samples at 3 points collected in 2014 from the very periphery of the brownfield with no construction going on (site S-II), 3) samples at 4 points collected in 2015 again from the central part of the brownfield but already lacking the topsoil layer which together with the demolished building wreckage was removed during the construction works (site S-III).

Sampling strategy, soil preparation and chemical analysis for potentially harmful elements (PHEs) were done according to the published methodologies (Čèsnienè et al., 2014; Taraškevičius et al., 2016). 15 PHEs (As, Ba, Cd, Co, $\mathrm{Cr}, \mathrm{Cu}, \mathrm{Hg}, \mathrm{Mn}, \mathrm{Mo}, \mathrm{Ni}, \mathrm{Pb}, \mathrm{Se}, \mathrm{Sn}, \mathrm{V}, \mathrm{Zn}$ ) were used to calculate the total contamination index Zs (Krasilsčikovas et al., 1988). The background level of the elements was determined in soil samples from 8 uncontaminated sites around the city.

\section{Treatment of Tradescantia cuttings with soil extracts}

Tradescantia clone \#4430 plants were prepared, grown ant cuttings treated for $6 \mathrm{~h}$ with the aqueous and organic (5\% dimethyl sulphoxide, DMSO) (Sigma, USA) soil extracts according to the standardized methodology for the application of two bioassays, Trad-SHM and Trad-MN (Ma, 1981; Ma et al., 1994). The following genotoxicity parameters were evaluated: frequency of pink cell (PC), colourless cell (CC), branched hair $(\mathrm{BH})$ and micronuclei $\mathrm{MN}$.

\section{Growing Allium bulbs in test soil and analysis}

Common onion Allium cepa was prepared and grown according to the standardized procedure (Fiskesjö, 1985) with a $12 \mathrm{~h}$ root initiation in tap water before planting 6 bulbs into each soil sample in 3 replicates. Tap water was used as a negative control $\left(\mathrm{C}-\mathrm{H}_{2} \mathrm{O}\right)$, the uncontaminated soil was used as a background control $(\mathrm{C}-\mathrm{Bn})$ and $10 \mathrm{mg} \mathrm{L}^{-1} \mathrm{methyl}$ methanesulfonate (MMS) (Sigma, USA) - as a positive control (C-MMS). The following parameters were evaluated for diverse duration of bulb growth in the soil: root growth inhibition index (RGI) after $96 \mathrm{~h}$, mitotic index $\left(\mathrm{MI}_{24}\right)$ and chromosome aberration (CA) frequency after $24 \mathrm{~h}$, and mitotic index $\left(\mathrm{MI}_{48}\right)$ and micronuclei frequency (Allium-MN) after $24 \mathrm{~h}$ growth in soil with afterward $24 \mathrm{~h}$ recovery period in tap water. Cytogenetic indices were calculated according to the standardized methodology (Rank, Nielsen, 1993).

\section{RAPD and ISSR amplification}

Total DNA was extracted with Genomic DNA Purification Kit (ThermoFisher Scientific, Lithuania) from Allium roots grown in test soil for $96 \mathrm{~h}$. DNA from 6 onions per each soil point were combined into a composite DNA sample.

Six primers (Metabion, Germany) were used in RAPD analysis: B389, BC374, OPA01, OPA03, OPA13 and OPB10. PCR was performed in $8 \mu \mathrm{L}$ of the final volume containing $60 \mathrm{ng}$ DNA, $0.2 \mathrm{mM} \mathrm{dNTP}, 0.5 \mu \mathrm{M}$ primer, $0.15 \mathrm{U}$ DreamTaq DNA polymerase (ThermoFisher Scientific, Lithuania). PCR was performed as follows: 2 min initial denaturation at $95^{\circ} \mathrm{C} ; 45$ cycles of $1 \mathrm{~min}$ at $95^{\circ} \mathrm{C}, 1 \mathrm{~min}$ at $36^{\circ} \mathrm{C}$ and $2 \mathrm{~min}$ at $72^{\circ} \mathrm{C}$; and final extension for $8 \mathrm{~min}$ at $72^{\circ} \mathrm{C}$.

Four primers were utilized in ISSR analysis: UBC808, UBC809, UBC857 and UBC886. PCR performed in $10 \mu \mathrm{L}$ of the final volume containing $60 \mathrm{ng}$ DNA, $0.2 \mathrm{mM}$ dNTP, $0.4 \mu \mathrm{M}$ primer, $0.5 \mathrm{U}$ DreamTaq DNA polymerase. PCR was performed as follows: 3 min initial denaturation at $95^{\circ} \mathrm{C} ; 38$ cycles of $30 \mathrm{~s}$ at $95^{\circ} \mathrm{C}, 30 \mathrm{~s}$ of primer annealing and $100 \mathrm{~s}$ at $72^{\circ} \mathrm{C}$; and final extension for $10 \mathrm{~min}$ at $72^{\circ} \mathrm{C}$ in Mastercycler ${ }^{\circledR}$ Gradient (Eppendorf, Germany). 


\section{Statistical analysis}

Differences between the means were evaluated by one-way ANOVA being significant with p-value $\leq 0.05$ and induction of genotoxic effects by $\chi^{2}$-test in GraphPad Instat (GraphPad Software, Inc., www.graphpad.com). Spearman rank correlation coefficients were calculated in Statistica v7 (StatSoft. Inc., www.statsoft.com) and multiple regression analysis performed in Statgraph v2.1 (Santos, Fujita, 2017).

The electrophoretic data was codified as (1) for the presence of bands and (0) for their absence. Binary data were analysed using 1000 permutations and UPGMA dendrograms generated in TreeCon v1.3b (Van de Peer, De Wachter, 1994). Genetic distance matrices were compared performing a Mantel test in GenAlEx v6.5 (Peakall, Smouse, 2012).

\section{RESULTS AND DISCUSSION}

\section{Soil sample characterisation}

A topography plays an important role in the dispersion of the pollutants in the area (Abril et al., 2014) and this was taken into account when choosing sampling points at the brownfield: soil was collected at the incline of the slope from all the factory buildings leaving the main pollution source upwards of the sampling points. Chemical analysis revealed that the whole territory is extremely polluted with high levels of heavy metals (Table 1). Each of the 15 PHEs exceeded background levels (data not shown) in at least 4 soil samples, thus all PHEs were used to determine the total contamination level at each soil sampling point. Total concentrations of PHEs at all sampling points from the same site were averaged and used to calculate an average total contamination index for the overall sampling site. The highest total contamination assigned to the extremely hazardous level was determined in the soil samples collected from the central part of the brownfield (site S-I) in 2013 before the recultivation started. The total contamination in S-II soil samples varied in a narrow range Zs $=16-137$, and in S-III samples - from 52 to 289. All soil samples had a variable amount, from 2 in S4-III to 11 in S6-I, of elements exceeding the highest permissible concentration (HPC) (Table 1) (HN 60-2015). S2-II was the only soil sample in which all 15 PHEs did not exceed the HPC but still was assigned to the moderate pollution level as its total contamination exceeded the permissible level (Zs = 6-16) applicable to the clean areas (Gregorauskiene et al., 2011; Kumpiene et al., 2011). The multiple regression analysis revealed that $\mathrm{Cu}$, Se and $\mathrm{Sn}$ had the greatest influence on the soil total contamination index (Zs) values. Soil samples bearing the largest amount of PHEs exceeding HPC were selected for further analysis in the plant test-systems (Table 1).

Table 1. Soil sampling points with averaged site characteristics, and two plant test-systems employed in soil genotoxicity analysis using cytogenetic $\left(^{1}\right)$ and molecular $\left(^{2}\right)$ markers

\begin{tabular}{|c|c|c|c|c|}
\hline $\begin{array}{l}\text { Sample } \\
\text { point/site }\end{array}$ & Potentially harmful elements & $\mathrm{Zs}$ & Hazard level & $\begin{array}{l}\text { Plant } \\
\text { test-system }\end{array}$ \\
\hline S1-I & $\mathrm{Cd}(6) \mathrm{Cr}(4) \mathrm{Cu}(4) \mathrm{Mo}(1.4) \mathrm{Ni}(3) \mathrm{Pb}(2) \mathrm{Sn}(3) \mathrm{Zn}(3)$ & 204 & extremely hazardous & Tradescantia $^{1}$ \\
\hline S2-I & $\begin{array}{l}\mathrm{Ba}(1.3) \mathrm{Cd}(3) \mathrm{Cr}(5) \mathrm{Cu}(\mathbf{5 8}) \mathrm{Mo}(3) \mathrm{Ni}(2) \mathbf{P b}(\mathbf{1 1}) \mathbf{S e}(\mathbf{8 4}) \mathbf{S n}(\mathbf{1 9}) \\
\operatorname{Zn}(\mathbf{2 6})\end{array}$ & 1802 & extremely hazardous & Tradescantia ${ }^{1}$ \\
\hline S3-I & $\begin{array}{l}\mathrm{Ba}(1.3) \mathrm{Cd}(2) \mathrm{Cr}(4) \mathrm{Cu}(\mathbf{4 6}) \mathrm{Mo}(4) \mathrm{Ni}(2) \mathrm{Pb}(6) \mathrm{Se}(\mathbf{2 0}) \mathbf{S n}(11) \\
\mathbf{Z n}(27)\end{array}$ & 1128 & extremely hazardous & Tradescantia ${ }^{1}$ \\
\hline S4-I & $\mathrm{Cd}(8) \mathbf{C r}(13) \mathbf{C u}(\mathbf{1 9}) \mathrm{Hg}(5) \mathrm{Mo}(3) \mathbf{N i}(12) \mathrm{Pb}(9) \mathbf{S n}(13) \mathbf{Z n}(\mathbf{2 1})$ & 803 & extremely hazardous & Tradescantia $^{1}$ \\
\hline S5-I & $\mathrm{Cd}(4) \mathrm{Cr}(4) \mathrm{Cu}(5) \mathrm{Ni}(3) \mathrm{Pb}(2) \mathrm{Sn}(1.5) \mathrm{Zn}(5)$ & 200 & extremely hazardous & Tradescantia $^{1}$ \\
\hline S6-I & $\begin{array}{l}\operatorname{As}(1.3) \operatorname{Cd}(8) \operatorname{Cr}(9) \operatorname{Cu}(\mathbf{2 6}) \mathrm{Hg}(5) \mathrm{Mo}(2) \mathrm{Ni}(2) \mathbf{P b}(\mathbf{4 1}) \mathrm{Se}(2) \\
\operatorname{Sn}(\mathbf{1 2}) \mathrm{Zn}(9)\end{array}$ & 874 & extremely hazardous & $\begin{array}{l}\text { Allium }^{1,2} \\
\text { Tradescantia }^{1}\end{array}$ \\
\hline S7-I & $\mathrm{Cd}(6) \operatorname{Cr}(\mathbf{1 0}) \mathbf{C u}(\mathbf{1 4}) \mathrm{Mo}(2) \mathrm{Ni}(3) \mathrm{Pb}(5) \operatorname{Sn}(8) \mathrm{Zn}(9)$ & 451 & extremely hazardous & Tradescantia $^{1}$ \\
\hline S8-I & $\mathrm{Cd}(3) \mathrm{Cr}(2) \mathrm{Cu}(4) \mathrm{Hg}(4) \mathrm{Mo}(1.3) \mathrm{Ni}(2) \mathrm{Pb}(1.2) \mathrm{Zn}(8)$ & 206 & extremely hazardous & Tradescantia ${ }^{1}$ \\
\hline S9-I & $\begin{array}{l}\mathrm{Cd}(2) \mathrm{Cr}(3) \mathrm{Cu}(11) \mathrm{Hg}(3) \mathrm{Mo}(3) \mathrm{Ni}(1.03) \mathrm{Pb}(4) \mathrm{Se}(4) \mathrm{Sn}(2) \\
\mathrm{Zn}(5)\end{array}$ & 296 & extremely hazardous & Tradescantia ${ }^{1}$ \\
\hline site $S-I$ & $\begin{array}{l}\mathrm{Cd}(4) \mathrm{Cr}(6) \mathrm{Cu}(\mathbf{2 6}) \mathrm{Hg}(4) \mathrm{Mo}(2) \mathrm{Ni}(3) \mathrm{Pb}(9) \mathrm{Se}(\mathbf{1 5}) \mathrm{Sn}(9) \\
\mathrm{Zn}(\mathbf{1 4})\end{array}$ & 780 & extremely hazardous & \\
\hline S1-II & $\mathrm{Cd}(1.3) \mathrm{Cr}(1.1) \mathrm{Cu}(1.2) \mathrm{Zn}(1.1)$ & 56 & hazardous & \\
\hline S2-II & - & 16 & moderately hazardous & \\
\hline S3-II & $\mathrm{Cd}(2) \mathrm{Cr}(1.4) \mathrm{Cu}(5) \mathrm{Mo}(1.1) \mathrm{Pb}(3) \mathrm{Zn}(3)$ & 137 & extremely hazardous & Allium $^{1,2}$ \\
\hline site $S$-II & $\mathrm{Cd}(2) \mathrm{Cr}(1.4) \mathrm{Cu}(5) \mathrm{Mo}(1.1) \mathrm{Pb}(3) \mathrm{Zn}(3)$ & 69 & hazardous & \\
\hline S1-III & $\mathrm{Cd}(1.2) \mathrm{Cr}(1.4) \mathbf{C u}(\mathbf{1 6}) \mathrm{Mo}(2) \mathrm{Pb}(2) \mathrm{Sn}(1.3) \mathrm{Zn}(3)$ & 289 & extremely hazardous & Allium $^{1,2}$ \\
\hline S2-III & $\mathrm{Cd}(2) \mathrm{Cu}(2) \mathrm{Hg}(2) \mathrm{Pb}(1.3) \mathrm{Zn}(3)$ & 99 & hazardous & Allium $^{1,2}$ \\
\hline S3-III & $\mathrm{Cd}(2) \mathrm{Mo}(2) \mathrm{Pb}(9)$ & 94 & hazardous & Allium $^{2}$ \\
\hline S4-III & $\mathrm{Cd}(2) \operatorname{Mo}(2)$ & 52 & hazardous & Allium $^{1,2}$ \\
\hline site $S$-III & $\mathrm{Cd}(2) \mathrm{Cu}(6) \mathrm{Hg}(1.2) \mathrm{Mo}(2) \mathrm{Pb}(1.2) \mathrm{Zn}(2)$ & 133 & extremely hazardous & \\
\hline
\end{tabular}

Only potentially harmful elements (PHEs) exceeding the highest permissible concentration (HPC) are listed with the exceeding magnitude given in brackets, PHEs exceeding HPC more than 10-fold are in bald; Zs - total contamination index for soil; S1 - sampling point at the site; S-I - sampling site in 2013; S-II - in 2014; S-III - in 2015; values for the sites represent averaged PHE content from all sampling points at that site

Topsoil removal during brownfield recultivation has resulted in almost 6-fold pollution decrease in the central part of the brownfield and dropped from $\mathrm{Zs}=780$ in 2013 to $\mathrm{Zs}=133$ in 2015, but yet remained as extremely polluted and possessing extreme hazard to human health as that high total contamination in soil is related to the induction of various chronic diseases, especially in children (Kumpiene et al., 2011; Gorbunov et al., 2015; Khan et al., 2015). Much higher concentrations of heavy metals in the soil were determined in the present work in comparison to the levels found in other intensively liberated soils contaminated with various waste (Kumpiene et al. 2011; Bondzinskaitè et al. 2017; Čèsniené 
et al. 2017) or highly contaminated soil from Bijie city in China (Yuan et al., 2017), however Zs values in our research were similar to those detected in soil from a well-developed industrial cities (Gorbunov et al., 2015).

\section{Genotoxicity effects of water/DMSO soil extracts in Tradescantia cuttings}

The genotoxicity of soil samples from nine points within the S-I site using Tradescantia tests was evaluated in 2013 before the recultivation of the brownfield was started. In our research, the main concern is addressed to the topsoil that has been removed and what possible genotoxic impact on the environment it can load if not managed appropriately or even worse - reused for rural environment improvement like road restoration, where from its dangerous compounds can spread by leaching. In general, $\mathrm{MN}$ frequency in cuttings treated with $\mathrm{H}_{2} \mathrm{O}$ extracts of all tested soil samples varied in a narrow range but was significantly higher than in control with the exception of S8-I (Fig. 1D). Some studies with Tradescantia have shown that the MN test is significantly more sensitive than PC (Kong, Ma, 1999; Fadic et al., 2017).

A similar trend was found in $\mathrm{CC}$ and BH tests both in this study and in Čèsnienè et al. (2010). Similar dynamics were observed in the case of PC (Fig. 1A), the highest PC frequency was induced in S9-I $\mathrm{H}_{2} \mathrm{O}$ and S5-I DMSO extracts. Despite observed appreciable differences between the $\mathrm{H}_{2} \mathrm{O}$ and DMSO soil extracts at some points, the average PC frequencies induced by $\mathrm{H}_{2} \mathrm{O}$ and DMSO soil extracts differed insignificantly. In three cases (S5-I, S8-I and S9-I) MN frequency observed in DMSO extracts was significantly higher than induced by $\mathrm{H}_{2} \mathrm{O}$ extracts, indicating that in some points soil is contaminated not only with heavy metals but also contains genotoxic organic materials, as was demonstrated by Kong and Ma (1999), studying soil contaminated with pesticides.

$\mathrm{CC}$ frequency in all cases exceeded the control values and was twice higher than PC (Fig. 1B). Although a high frequency of CC was induced by S9-I $\mathrm{H}_{2} \mathrm{O}$ extract, the highest $\mathrm{CC}$ value was determined in S3-I. BH frequency values were similar to PC frequencies (Fig. 1C), but variation among the test points was higher than in case of MN, PC or CC. The highest frequency of $\mathrm{BH}$ was induced by $\mathrm{S} 1-\mathrm{I} \mathrm{H}_{2} \mathrm{O}$ and DMSO extracts.
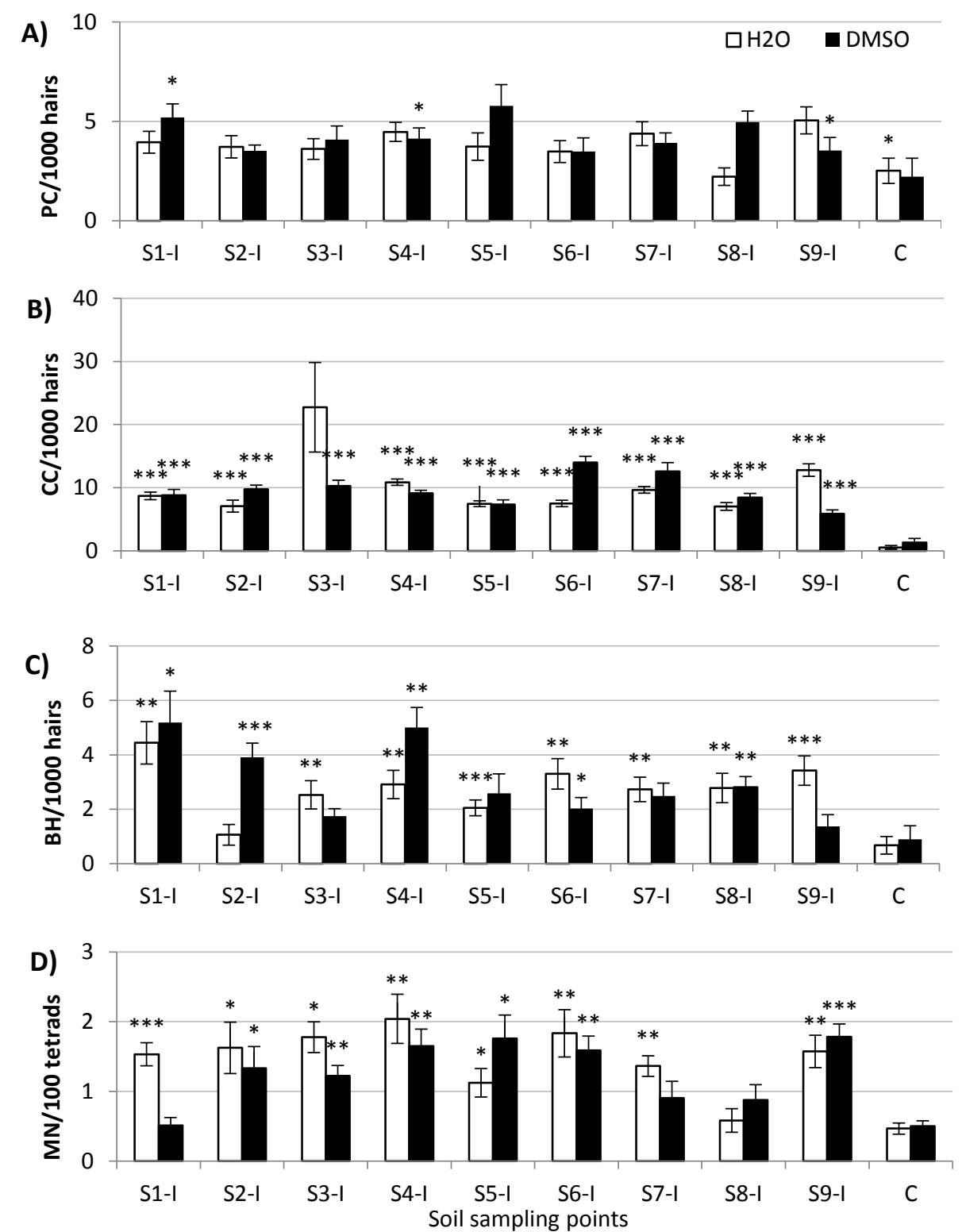

Figure 1. Genotoxicity effects of aqueous $\left(\mathrm{H}_{2} \mathrm{O}\right)$ and organic (DMSO) S-I site soil extracts in Tradescantia cuttings A) Frequency of pink cell (PC) mutation; B) Colorless cell (CC); C) Branched hair (BH); D) Micronucleus (MN) induction; C - control. Bars indicate the standard deviation $(\mathrm{SD}) ; * \mathrm{P}<0.05 ; * * \mathrm{P}<0.01 ; * * * \mathrm{P}<0.001$ compared to the respective control 
Although all tested soil samples at the abandoned 'Skaiteks' factory site S-I were extremely highly polluted compared to other soils studied in our previous work (Čèsnienė et al., 2010), and their Zs values varied significantly (from 200 to 1802), however, the Zs values of the soils did not correlate with the results of genotoxicity response bioindicators obtained with Trad-tests (PC, CC, BH), what is in agreement with Majer et al. (2002). However, a multiple linear regression analysis showed that the concentration of some PHEs in the soil correlates with some bioindicators: the frequency of PC-DMSO correlates with $\mathrm{Mo}$ and $\mathrm{Pb}$ concentrations in soil, CC- $\mathrm{H}_{2} \mathrm{O}$ - with Mo and Sn, CC-DMSO - with As, $\mathrm{BH}-\mathrm{H}_{2} \mathrm{O}$ - with Se and $\mathrm{BH}-\mathrm{DMSO}$ - with Ni. Moreover, no association was observed between the metal content in soil and induction of $\mathrm{MN}$, which is considered the universal method for the genotoxicity evaluation in both plant and animal test-systems. Hence, our work highlights the importance of using a battery of biological tests aside from the results of soil chemistry as well as the necessity of correct soil sample selection by covering the entire test-area, as there are significant geochemical differences between the individual soil sampling points. Thus, the S6-I soil sample, reflecting the general trend of the genotoxic soil exposure-response in Tradescantia and also containing the richest bouquet of heavy metals exceeding the HPC values, was chosen for additional genotoxicity evaluation using Allium bioassays along with the other soil samples collected in subsequent years from the same territory (Table 1).

\section{Soil exposure effects in Allium}

Cytogenetic analysis. Five soil samples with the highest number of elements exceeding HPC were selected for the cytogenetic analysis in Allium test-system (Table 1). The last sampling done in 2015 represents how much of the primary pollution was removed from the site and the biggest concerns should be addressed to appropriate management, storage or utilization of the removed soil ensuring that it does not simply end up somewhere in the wild or rural environment for reuse in agriculture. The concern is also rising when the potential threat of toxicant leftovers from the previous pollution are met as in all S-III soil samples still exceeding background and HPC values (Table 1).

RGI test revealed that only S3-II soil significantly reduced onion root growth by $30 \%$ compared to negative control (Fig. 2A) suggesting the presence of inhibiting agents in the soil. On the contrary, S2-III and S4-III soils significantly stimulated onion root growth and the root bundle was longer by 48 and 38\%, respectively, when compared to negative control. Root length differences were insignificant in onions grown in the rest of the soils (Fig. 2A) alike in other studies using Allium where toxicity and cytotoxicity indices did not show significant responses (Oyeyemi, Bakare, 2013; de Souza Pohren et al., 2013). RGI showed insignificant dependence on the total soil contamination $(r=0.59, p>0.05)$ prompting that onion root growth might be determined by other compounds than PHEs in the test soil as was supposed from the results of organic S-I soil extract in Trad-MN test and moreover root growth does not simply involve cell proliferation, but is also a function of cell elongation dependent on various enzymes (Silveira et al., 2017).


Figure 2. Cytotoxicity (A) and genotoxicity (B) effects of soil samples over different exposure time in Allium root tips C-MMS - positive control; $\mathrm{C}-\mathrm{H}_{2} \mathrm{O}$ - negative control; C-Bn - background control; S1 - sampling point; S-I - sampling site; MI - mitotic index at 24 and $48 \mathrm{~h}$ intervals; RGI - root growth index; $\mathrm{MN}$ - micronuclei; CA - chromosome aberrations; $\mathrm{AC}$ - apoptotic cells. Bars indicate the standard error of the mean (SEM). $* \mathrm{P}<0.05 ; * * \mathrm{P}<0.01 ; * * * \mathrm{P}<0.001$ compared to the negative control

Overall MI range in onion root tip cells after variable durability of growth in the soil was 44-87 and 47-63\%o after 24 and 48 h, respectively (Fig. 2A) and this is in concordance with other studies (Ma et al., 1995; Kataeva et al., 2012). MI in Allium root tip cells did not change over time when onions were grown in the same soil for continuous 24 and $48 \mathrm{~h}$ period ( $\mathrm{p}>0.05$ ). Only two soil samples had a stimulating effect on onion root cell mitotic activity: S3-II soil after $24 \mathrm{~h}$ and S2-III after $48 \mathrm{~h}$ exposure when compared to the negative control $(\mathrm{p}<0.05)$. Analysis of the relative cell amount at different mitotic phases revealed no significant differences in onions grown in all soils indicating that there was no antiproliferative effect or distortions of the cell cycle. 
An alarming finding was discovered during cytological analysis of onion roots exposed to the soil S6-I, which induced a significant increase $(\mathrm{p}<0.01)$ of apoptotic cell $(\mathrm{AC})$ frequency compared to the negative control $(3.57$ and $0.18 \%$, respectively) (Fig. 2B) and AC amount was strongly dependent on root growth inhibition $(\mathrm{r}=0.92, \mathrm{p}<0.05)$. This exposure effect might be attributed to a high acute toxicity of the S6-I soil sample since the relation of apoptotic cell frequency was dose dependent to Cd concentration $(\mathrm{r}=0.91, \mathrm{p}=0.01)$. Cd is known to induce toxicological effects even at small doses, also it might be responsible for apoptotic cell increase (Oliveira et al., 2014; Khan et al., 2015). Cd concentration in our study exceeds HPC in all soil samples, but the S6-I soil sample has the highest Cd concentration $\left(11.5 \mathrm{mg} \mathrm{kg}^{-1}\right)$ and exceeds HPC 8-fold. The same cytotoxic effect was described in studies of onion root treatment with lethal concentrations of various metal compounds or genotoxic extracts (Kataeva et al., 2012; Oyeyemi, Bakare, 2013).

Chromosome aberration frequency in onion roots exposed to all soil samples, except S1-III, was higher than in unexposed onions, but the difference was nonsignificant. CA analysis revealed that only S6-I and S4-III soils increased CA frequency significantly ( $\mathrm{p}<0.001$ and $<0.05$, respectively). The most commonly occurring aberrant alterations were fragments and bridges, both arising from the clastogenic action of analysed soils. In our research, exposure of $24 \mathrm{~h}$ durability for $\mathrm{CA}$ induction might be insufficient/excess for different soil samples because significantly different root length was recorded during root fixation meaning that different soil samples with variable contamination had an inconsistent effect on onion root cell cycle speed. While roots of 2-3 cm are the most suitable for cytological analysis (Ma et al., 1995), in our survey of such heterogeneous soil samples, the exposure time cannot be easily unified. Suggestion for the future studies would be to do more fixation steps after shorter periods of root exposure to the soil, with increments as short as $12 \mathrm{~h}$ to catch the time points when CA frequency is at the peak of its observation.

On the contrary, in Allium-MN analysis all soil samples induced elevated levels of $\mathrm{MN}$ in onion root cells compared to negative control ( $\mathrm{p}<0.001)$, while in onions exposed to background soil, induction of MN was significantly lower (Fig. 2B). Soil sample S6-I had one of the lowest MN induction in opposite to its highest Zs index, but this soil induced the highest rate of apoptosis in onion root cells and the later effect was responsible for the reduction of nonapoptotic interphase cells suitable for MN evaluation. MN formation might be attributed to various mechanisms (Khan et al., 2015; Fenech et al., 2016; Silveira et al., 2017), clastogenic or aneugenic, as a bunch of different PHEs are involved (Table 1), but their interactions (antagonistic, synergistic) are not revealed in our case. Interactions between elements are also of similar importance to deficiency and toxicity in the physiology of plants, and their imbalanced reactions may cause a real chemical stress in plants (Kabata-Pendias, 2011).

$\mathrm{CA}$ and MN frequency in Allium bioassay were related by significant correlation $(\mathrm{r}=0.73, \mathrm{p}<0.05)$, similar relationship determined between CA after $24 \mathrm{~h}$ exposure and apoptotic cell frequency after $48 \mathrm{~h}$ exposure $(\mathrm{r}=0.76$, $\mathrm{p}>0.05)$, whereas CA with RGI correlated insignificantly $(r=0.60, p>0.05)$. Mitotic index showed no clear relation with the rest Allium test indices or with the total contamination index $\mathrm{Zs}(\mathrm{p}>0.05)$ independently on the duration of exposure, except correlation between $\mathrm{MI}_{48}$ and Allium-MN frequency $(\mathrm{r}=0.483, \mathrm{p}>0.05)$ indicating that in this case the mitotic machinery was stimulated along with the deleterious effects of soils and similar MI trend was detected in onions exposed to industrial effluents only with small amounts of heavy metals (Dane et al., 2006). There are studies where toxicity and cytotoxicity indices did not show any significant responses (de Souza Pohren et al., 2013).

Molecular marker analysis in Allium. RAPD and ISSR markers were analysed for polymorphism changes in onion DNA after direct $96 \mathrm{~h}$ onion root exposure to the soil samples (Table 1). Six RAPD primers amplified 139 bands in total, of which 132 were polymorphic, while four ISSR primers generated 77 bands in total and 57 were polymorphic. Polymorphic bands were employed in the generation of genetic distance matrices further used for genetic relationship reconstruction. RAPD and ISSR dendrograms revealed an identical tendency - the most heavily polluted S6-I and S3-II soils have induced similar genetic changes in onion roots but different from the effect of S-III soil sampled in 2015 after topsoil removal from the brownfield (Fig. 3).

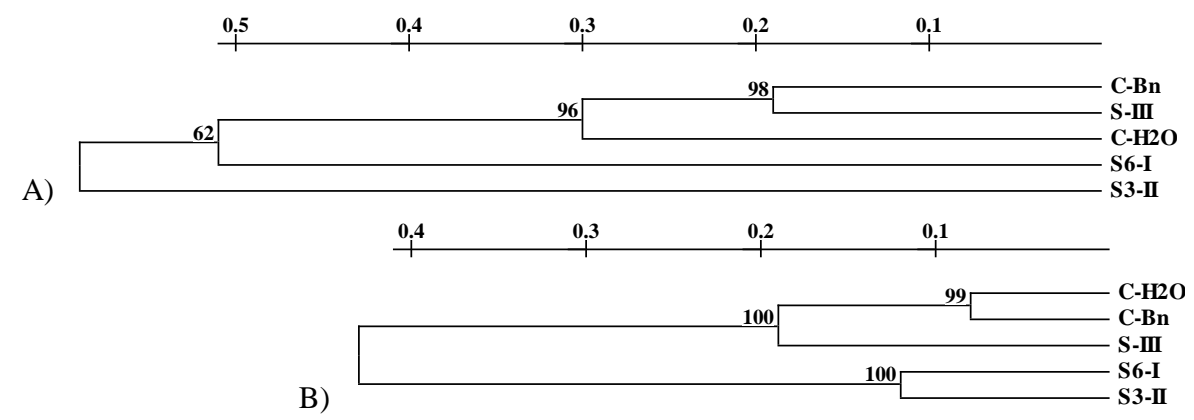

Figure 3. UPGMA dendrograms among treated and untreated Allium using RAPD (A) and ISSR (B) biomarkers Nei's genetic distance presented on the axis, bootstrap values (\%) from 1000 permutations given at the branch nodes. C- $\mathrm{H}_{2} \mathrm{O}-$ negative control; C-Bn - background soil control; S-I - sampling site; S3 - sampling point

Mantel test, correlating genetic distance matrices generated from RAPD and ISSR data, revealed concordance between polymorphism results of both marker systems $(r=0.862, p=0.001)$ indicating that S-III soil sampled in 2015 has a different access to DNA material and induces different exposure effects with fewer mutation events compared to S6-I or S3-II soil and is clustered together with the control onion samples grown in tap water and soil with low background levels of elements (Fig. 3). Though results from application of two types of molecular biomarkers indicate a change in 
the amplification profiles of exposed and unexposed onions nevertheless our results do not have the same tendency of dose-dependent band loss and gain resulting from Allium exposure to the tested compounds as in most other studies (Conte et al., 1998; Bernardes et al., 2015) and it also remains unclear how every single element performs in a complex environmental sample as in this case - topsoil enriched with a bunch of PHEs.

In our study, RAPD and ISSR analysis confirms that both marker systems can be applied to evaluate how the environmental pollutants modify the structure of DNA in living organisms (Conte et al., 1998; Bernardes et al., 2015) since both dendrograms (Fig. 3) clearly show genetic divergence among onions grown in S6-I soil sampled before the site recultivation start and onions grown in the soil from the same site (S-III) but with the topsoil removed during revitalization process. We conclude that different combination of heavy metals is responsible for toxicity in plants, also induce oxidative stress and alterations in DNA damage response (Al-Qurainy, 2010).

Plant test-systems can detect a wide range of genetic damage both at the chromosomal and DNA level. Soil genotoxicity assessment by the application of plant bioassay battery gives a more complex view into potentially harmful effects in living organisms exposed to the polluted soil as the response might be inconsistent in organisms of different sensitivity and tolerance. Tradescantia and Allium are biological indicator plants suitable for assessment of soil quality in environments affected by human activities. Both plant test-systems in this study confirm that soil from the brownfield is harmful to plants and is potentially hazardous to people and special care must be taken into assuring cleaning of such ecological risk areas when transforming into residential zones. Moreover, topsoil removed from the contaminated areas must be handled according to the regulations ensuring that it is not deposited inappropriately or reused negligently. Hence, our work highlights the importance of using a battery of biological tests together with soil chemical analysis, and correct plan for sustainable development of contaminated sites must be prepared in advance and monitoring must be done during all revitalization process to assure that leftovers of previous contamination are no longer present. In addition, the same battery of biological tests can be used for the analysis of detoxified soil to assure it is no longer hazardous.

\section{CONCLUSIONS}

Soil from the brownfield was subjected to the soil genotoxicity assessment using model plants. Chemical analysis revealed highly elevated concentrations of potentially harmful elements. The highest total contamination was determined in the brownfield soil collected before the recultivation start and its pollution extent was assigned to the extremely hazardous level and all cytogenetic markers were elevated in Tradescantia plant cuttings exposed to its extracts, both aqueous and organic. Nevertheless, the brownfield encountered a recultivation process during 3-year monitoring period with topsoil removed from the site, a frequency of Allium-MN remained elevated and even increased by 2 -fold indicating the primary acute toxicity by the most heavily contaminated soil as was seen from an alarming increase of apoptotic cells in onion roots. No inhibition of root growth or mitodepressive effect on Allium cell division was attributed to the total soil contamination. Frequencies of chromosome aberrations and micronuclei were related by significant correlation but lacking a significant relation to the total soil contamination in Allium bioassay. Cluster analysis of Allium molecular biomarkers separated onions grown in the least contaminated soil from the onions grown in the most polluted soil. Soil pollution at the study site was gradually diminishing as removal of the topsoil resulted in metal concentration decrease, but that was insufficient to reduce its toxic and genotoxic effects in Allium to background or negative control levels.

Acknowledgements. This work was supported by a grant from the Lithuanian Research Council MIP-042/2015.

\section{REFERENCES}

1. Abril, G.A., Wannaz, E.D., Mateos, A.C., Invernizzi, R., Plá, R.R., Pignata, M.L. 2014. Characterization of atmospheric emission sources of heavy metals and trace elements through a local-scale monitoring network using T. capillaris. Ecological Indicators, Vol. 40, pp. 153-161. https://doi.org/10.1016/j.ecolind.2014.01.008

2. Aguiar, L.L., Andrade-Vieira, L.F., de Oliveira David, J. A. 2016. Evaluation of the toxic potential of coffee wastewater on seeds, roots and meristematic cells of Lactuca sativa L. Ecotoxicology and Environmental Safety, Vol. 133, pp. 366-372. https://doi.org/10.1016/j.ecoenv.2016.07.019

3. Al-Qurainy, F. 2010. Application of inter simple sequence repeat (ISSR marker) to detect genotoxic effect of heavy metals on Eruca sativa (L.). African Journal of Biotechnology, Vol. 9, pp. 467-474.

4. Bernardes, P.M., Andrade-Vieira, L.F., Aragão, F.B., Ferreira, A., da Silva Ferreira, M.F. 2015. Toxicity of difenoconazole and tebuconazole in Allium cepa. Water, Air, \& Soil Pollution, Vol. 226, pp. 207. https://doi.org/10.1007/s11270-015-2462-y

5. Bleicher, A., Gross, M. 2010. Sustainability assessment and the revitalization of contaminated sites: operationalizing sustainable development for local problems. International Journal of Sustainable Development \& World Ecology, Vol. 17, pp. 57-66. https://doi.org/10.1080/13504500903488263

6. Bondzinskaitè, S., Kleizaitè, V., Žvingila, D., Šiukšta, R., Čèsnienė, T. 2017. Genotoxicity assessment of polluted soils from Vilnius city using Tradescantia clone \#4430. Žmogaus ir Gamtos Sauga, pp. 66-69.

7. Chandra, S., Chauhan, L.K.S., Murthy, R.C., Saxena, P.N., Pande, P.N., Gupta, S.K. 2005. Comparative biomonitoring of leachates from hazardous solid waste of two industries using Allium test. Science of the Total Environment, Vol. 347, pp. 46-52. https://doi.org/10.1016/j.scitotenv.2005.01.002

8. Conte, C., Mutti, I., Puglisi, P., Ferrarini, A., Regina G., Maestri, E., Marmiroli, N. 1998. DNA fingerprinting analysis by a PCR based method for monitoring the genotoxic effects of heavy metals pollution. Chemosphere, Vol. 37, pp. 2739-2749.

9. Cotelle, S., Masfaraud, J.F., Férard, J.F. 1999. Assessment of the genotoxicity of contaminated soil with the Allium/Vicia- 
micronucleus and the Tradescantia-micronucleus assays. Mutation Research/Fundamental and Molecular Mechanisms of Mutagenesis, Vol. 426, pp. 167-171. https://doi.org/10.1016/S0027-5107(99)00063-9

10. Čèsnienè, T., Kleizaite, V., Bondzinskaite, S., Taraškevičius, R., Žvingila, D., Šiukšta, R., Rančelis, V. 2017. Metal bioaccumulation and mutagenesis in a Tradescantia clone following long-term exposure to soils from urban industrial areas and closed landfills. Mutation Research/Genetic Toxicology and Environmental Mutagenesis, Vol. 823, pp. 65-72. https://doi.org/10.1016/j.mrgentox.2017.09.004

11. Čèsnienè, T., Kleizaitè, V., Rančelis, V., Žvingila, D., Švabauskas, K., Taraškevičius, R. 2014. Use of Tradescantia clone 4430 for direct long-term soil mutagenicity studies. Mutation Research/Genetic Toxicology and Environmental Mutagenesis, Vol. 768, pp. 23-32. https://doi.org/10.1016/j.mrgentox.2013.12.010

12. Čèsnienè, T., Kleizaitè, V., Ursache, R., Žvingila, D., Radzevičius, A., Patamsyte, J., Rančelis, V. 2010. Soil-surface genotoxicity of military and urban territories in Lithuania, as revealed by Tradescantia bioassays. Mutation Research, Vol. 697, pp. 10-18. https://doi.org/10.1016/j.mrgentox.2010.02.004

13. Dane, F., Ekici, N., Aktas, Y.K. 2006. The effect of waste water on root growth and mitosis in onion (Allium cepa) root apical meristem. Asian Journal of Plant Sciences, Vol. 5, pp. 331-334. https://doi.org/10.3923/ajps.2006.331.334

14. de Souza Pohren, R., da Costa, T.C., Vargas, V.M.F. 2013. Investigation of sensitivity of the Allium cepa test as an alert system to evaluate the genotoxic potential of soil contaminated by heavy metals. Water, Air, \& Soil Pollution, Vol. 224, pp. 1460. https://doi.org/10.1007/s11270-013-1460-1

15. Fadic, X., Placencia, F., Domínguez, A.M., Cereceda-Balic, F. 2017. Tradescantia as a biomonitor for pesticide genotoxicity evaluation of iprodione, carbaryl, dimethoate and 4,4'-DDE. Science of The Total Environment, Vol. 575, pp. 146-151. https://doi.org/10.1016/j.scitotenv.2016.09.198

16. Fenech, M., Knasmueller, S., Bolognesi, C., Bonassi, S., Holland, N., Migliore, L., Palitti, F., Natarajan, A.T., Kirsch-Volders, M. 2016. Molecular mechanisms by which in vivo exposure to exogenous chemical genotoxic agents can lead to micronucleus formation in lymphocytes in vivo and ex vivo in humans. Mutation Research/Reviews in Mutation Research, Vol. 770, pp. 12-25. https://doi.org/10.1016/j.mrrev.2016.04.008

17. Fiskesjö, G. 1985. The Allium test as a standard in environmental monitoring. Hereditas, Vol. 102, pp. $99-112$. https://doi.org/10.1111/j.1601-5223.1985.tb00471.x

18. Gorbunov, A.V., Lyapunov, S.M., Okina, O.I., Frontasjeva, M.V., Pavlov, S.S., Iljchenko, I.N. 2015. Nuclear-physical analysis methods in medical geology: Assessment of the impact of environmental factors on human health. Physics of Particles and Nuclei, Vol. 46, pp. 424-451. https://doi.org/10.1134/S1063779615030065

19. Gregorauskienė, V., Taraškevičius, R., Kadūnas, V., Radzevičius, A., Zinkute, R. 2011. Mapping the Chemical Environment of Urban Areas, $1^{\text {st }}$ ed., John Wiley \& Sons, Ltd., UK. https://doi.org/10.1002/9780470670071.ch23

20. Kabata-Pendias, A. 2011. Trace Elements in Soils And Plants, $4^{\text {th }}$ ed., CRC Press, USA. https://doi.org/10.1201/b10158-25

21. Kataeva, M., Kotseruba, V., Terekhina, N., Kutlunina, N., Beljaeva, A. 2012. Allium root-micronucleus (Allium-MCN) test on the genotoxicity of soil samples contaminated with heavy metals. World Applied Sciences Journal, Vol. 17, pp. 992-1000.

22. Khan, A., Khan, S., Khan, M.A., Qamar, Z., Waqas, M. 2015. The uptake and bioaccumulation of heavy metals by food plants, their effects on plants nutrients, and associated health risk: a review. Environmental Science and Pollution Research, Vol. 22, pp. 13772-13799. https://doi.org/10.1007/s11356-015-4881-0

23. Kong, M.S., Ma, T.H. 1999. Genotoxicity of contaminated soil and shallow well water detected by plant bioassays. Mutation Research/Fundamental and Molecular Mechanisms of Mutagenesis, Vol. 426, pp. 221-228. https://doi.org/10.1016/S0027$\underline{5107(99) 00072-X}$

24. Krasilsčikovas, D., Jatulienė, N., Taraškevičius, R., Barysienė, R., Michailenko, N. 1988. Quality of outdoor environment and morbidity of preschool children in major industrial centre (in Lithuanian). Sveikatos Apsauga, Vol. 11, pp. 11-13.

25. Kumpiene, J., Brännvall, E., Taraškevičius, R., Aksamitauskas, Č., Zinkutè, R. 2011. Spatial variability of topsoil contamination with trace elements in preschools in Vilnius, Lithuania. Journal of Geochemical Exploration, Vol. 108, pp. 15-20. https://doi.org/10.1016/j.gexplo.2010.08.003

26. Ma, T.-H. 1981. Tradescantia micronucleus bioassay and pollen tube chromatid aberration test for in situ monitoring and mutagen screening. Environmental Health Perspectives, Vol. 37, pp. 85-90.

27. Ma, T.-H., Cabrera, G.L., Chen, R., Gill, B.S., Sandhu, S.S., Vandenberg, A.L., Salamone, M.F. 1994. Tradescantia micronucleus bioassay. Mutation Research/Fundamental and Molecular Mechanisms of Mutagenesis, Vol. 310, pp. 221-230. https://doi.org/10.1016/0027-5107(94)90115-5

28. Ma, T.-H., Xu, Z., Xu, C., McConnell, H., Rabago, V.E., Arreola, A.G., Zhang, H. 1995. The improved Allium/Vicia root tip micronucleus assay for clastogenicity of environmental pollutants. Mutation Research/Environmental Mutagenesis and Related Subjects, Vol. 334, pp. 185-195. https://doi.org/10.1016/0165-1161(95)90010-1

29. Majer, B.J., Tscherko, D., Paschke, A., Wennrich, R., Kundi, M., Kandeler, E., Knasmüller, S. 2002. Effects of heavy metal contamination of soils on micronucleus induction in Tradescantia and on microbial enzyme activities: a comparative investigation. Mutation Research/Genetic Toxicology and Environmental Mutagenesis, Vol. 515, pp. 111-124. https://doi.org/10.1016/S1383$\underline{5718(02) 00004-9}$

30. Oyeyemi, I.T., Bakare, A.A. 2013. Genotoxic and anti-genotoxic effect of aqueous extracts of Spondias mombin L., Nymphea lotus L. and Luffa cylindrica L. on Allium cepa root tip cells. Caryologia, Vol. 66, pp. 360-367. https://doi.org/10.1080/00087114.2013.857829

31. Oliveira, H., Monteiro, C., Pinho, F., Pinho, S., Ferreira de Oliveira, J.M.P., Santos, C. 2014. Cadmium-induced genotoxicity in human osteoblast-like cells. Mutation Research/Genetic Toxicology and Environmental Mutagenesis, Vol. 775-776, pp.38-47. https://doi.org/10.1016/j.mrgentox.2014.10.002

32. Pal, S., Kundu, R. 2015. Heavy metal induced genotoxicity detection by RAPD in alligator weed. International Journal of Engineering Technology Science and Research 2, 2394-3386. 
33. Peakall, R., Smouse, P.E. 2012. GenAlEx 6.5: genetic analysis in Excel. Population genetic software for teaching and research an update. Bioinformatics, Vol. 28, pp. 2537-2539. https://doi.org/10.1093/bioinformatics/bts460

34. Rank, J., Nielsen, M.H. 1993. A modified Allium test as a tool in the screening of the genotoxicity of complex mixtures. Hereditas, Vol. 118, pp. 49-53. https://doi.org/10.1111/j.1601-5223.1993.t01-3-00049.x

35. Santos, S.S., Fujita, A. 2017. Statistical methods for graphs [R package statGraph version 0.1.0]. Comprehensive R Archive Network (CRAN).

36. Schädler, S., Morio, M., Bartke, S., Rohr-Zänker, R., Finkel, M. 2011. Designing sustainable and economically attractive brownfield revitalization options using an integrated assessment model. Journal of Environmental Management, Vol. 92, pp. 827-837. https://doi.org/10.1016/j.jenvman.2010.10.026

37. Silveira, G.L., Lima, M.G.F., Reis, G.B., Palmieri, M.J., Andrade-Vieria, L.F. 2017. Toxic effects of environmental pollutants: Comparative investigation using Allium cepa L. and Lactuca sativa L. Chemosphere, Vol. 178, pp. 359-367. https://doi.org/10.1016/j.chemosphere.2017.03.048

38. Silvia, C., Rosa, L., deSouza, R.B., Giuliano, D., Thiago, G. 2011. Soil Contamination, $1^{\text {st }}$ ed., InTech, Croatia. https://doi.org/10.5772/25042

39. Singh, S.K. 2017. Conceptual framework of a cloud-based decision support system for arsenic health risk assessment. Environment Systems and Decisions, Vol. 37, pp. 435-450. https://doi.org/10.1007/s10669-017-9641-x

40. Taraškevičius, R., Radžiūnienė, J., Zinkute, R., Petrauskienė, A., Jankauskaitė, M. 2016. Conditions to obtain results analysing a small amount of plant material by EDXRF. Chemija, Vol. 27, pp. 114-122.

41. Van de Peer, Y., De Wachter, R. 1994. TREECON for Windows: a software package for the construction and drawing of evolutionary trees for the Microsoft Windows environment. Computer Applications in the Biosciences: CABIOS, Vol. 10, pp. 569-570.

42. White, P.A., Claxton, L.D. 2004. Mutagens in contaminated soil: a review. Mutation Research/Reviews in Mutation Research, Vol. 567, pp. 227-345. https://doi.org/10.1016/j.mrrev.2004.09.003

43. Yuan, Z., Yao, J., Wang, F., Guo, Z., Dong, Z., Chen, F., Hu, Y., Sunahara, G. 2017. Potentially toxic trace element contamination, sources, and pollution assessment in farmlands, Bijie City, southwestern China. Environmental Monitoring and Assessment, Vol. 189, pp. 25. https://doi.org/10.1007/s10661-016-5755-8

44. Ziembińska-Buczyńska, A., Szulc, M., Zgórska, A. 2016. PCR-RAPD based estimation of hospital wastewater genotoxicity on Allium cepa. BioTechnologia, Vol. 3, pp. 195-201. https://doi.org/10.5114/bta.2016.62357 